\title{
PENGARUH MODEL PEMBELAJARAN POE (PREDICT-OBSERVE- EXPLAIN) TERHADAP PEMAHAMAN KONSEP FISIKA DITINJAU DARI GAYA BELAJAR SISWA
}

\author{
M. P. Restami \\ 1Teknik Komputer, Politeknik Ganesa Guru \\ primarestami@gmail.com
}

\begin{abstract}
ABSTRAK
Penelitian ini tergolong eksperimen semu dengan rancangan the post-test only control group design. Tujuan dari penelitian ini adalah untuk mengetahui adanya interaksi antara model pembelajaran dan gaya belajar terhadap peningkatan pemahaman konsep fisika. Sampel penelitian adalah siswa kelas X SMA Negeri 2 Tejakula sebanyak 57 orang. Pengambilan sampel menggunakan teknik simple random sampling yang dibagi ke dalam dua kelompok yaitu, kelompok eksperimen menggunakan model pembelajaran POE dan kelompok kontrol menggunakan model pembelajaran konvensional. Pengumpulan data menggunakan tes pemahaman konsep, gaya belajar, dan lembar observasi. Data dianalisis menggunakan statistik deskriptif dan pengujian hipotesis menggunakan ANOVA dua jalur. Hasil penelitian menunjukkan adanya pengaruh interaksi antara model pembelajaran dan gaya belajar terhadap peningkatan pemahaman konsep fisika $(F=11,000 ; p<0,05)$. Sehingga dapat disimpulkan bahwa dengan menggunakan model pembelajaran POE dan gaya belajar dapat mempengaruhi peningkatan pemahaman konsep yang dimiliki siswa. Penelitian ini memiliki keterlibatan terhadap suatu proses pembelajaran berdasarkan pada kemampuan dan pengalaman siswa agar dapat menciptakan sebuah proses pembelajaran yang bermakna serta mendapatkan hasil keluaran berupa pemahaman siswa terhadap konsep yang dipelajari.
\end{abstract}

Kata Kunci: Model POE, pemahaman konsep dan gaya belajar

\begin{abstract}
This research is classified as a quasi-experimental design with the post-test only control group design. The purpose of this study was to determine the interaction between learning models and learning styles towards increasing understanding of physics concepts. The research sample was 57 grade $X$ students of SMA Negeri 2 Tejakula. Sampling uses simple random sampling technique which is divided into two groups, namely, the experimental group uses the POE learning model and the control group using conventional learning models. Data collection uses concept understanding test, learning styles, and observation sheets. Data were analyzed using descriptive statistics and hypothesis testing using two-way ANOVA. The results of the study showed the influence of the interaction between learning models and learning styles on improving understanding of physics concepts $(F=11,000 ; p<0.05)$. So that it can be concluded that by using the POE learning model and learning style can influence the increase in students' understanding of concepts. This study has an involvement in a learning process based on the ability and experience of students to be able to create a meaningful learning process and get the output in the form of student understanding of the concepts learned.
\end{abstract}

Keywords: POE model, understanding the concept, and learning styles 


\section{PENDAHULUAN}

IImu Pendidikan adalah dua kata yang dipadukan, yakni IImu dan Pendidikan dimana dari masing-masing kata memiliki arti dan makna tersendiri. IImu adalah pengetahuan tentang suatu bidang yang dapat tersusun secara bersistem menurut metode tertentu, yang dapat digunakan untuk menerangkan atau menjelaskan suatu gejala tertentu di bidang pengetahuan, sedangkan pendidikan adalah suatu kebutuhan yang dimiliki oleh manusia. Manusia dalam kehidupannya memperlihatkan bahwa mereka memerlukan suatu proses pembelajaran yang memungkinkan dirinya untuk menyatakan eksistensinya secara utuh dan seimbang. Manusia untuk memahami jati diri dan menjadi dirinya sendiri perlu proses belajar terlebih dahulu untuk dapat hidup secara langsung. Dalam dunia pendidikan ada yang namanya pembelajaran, pembelajaran adalah suatu proses pemerolehan ilmu dan pengetahuan, penguasaan kemahiran dan tabiat serta pembentukan kepercayaan dan sikap pada peserta didik yang diberikan oleh para pendidik [9]. Dari proses pembelajaran peserta didik akan memperoleh suatu hasil dari pembelajaran tersebut, yang secara umum disebut dengan suatu hasil dari pengajaran dan merupakan tujuan dari pembelajaran, namun untuk memperoleh hasil yang optimal suatu proses pembelajaran harus dilakukan secara sadar dan terencana serta terorganisasi secara baik agar memperoleh suatu hubungan timbal balik antara guru dan siswa dalam proses pembelajaran berlangsung [1].

Namun kenyataannya pembelajaran yang terjadi saat ini di sekolah masih banyak yang berorientasi dengan upaya suatu pengembangan dan menguji daya ingat siswa. Namun proses pembelajaran masih cenderung berbasis hafalan teori dan tidak didasarkan pada pengalaman siswa, sehingga kemampuan siswa sekedar dipahami sebagai kemampuan menghafal. Berbagai faktor dipandang dapat mempengaruhi hasil belajar/pemahaman konsep siswa. Salah satu faktor penting dalam proses pembelajaran yaitu penerapan model pembelajaran yang dilakukan guru. Model pembelajaran yang diterapkan oleh guru masih monoton dengan mengimplementasikan model pembelajaran yang yang mampu memproses informasi yang didapatkan pada saat proses pembelajaran berlangsung. Guru lebih sering memberikan informasi dalam bentuk yang sudah jadi, seperti konsep-konsep atau rumus-rumus yang sudah ada di buku, kemudian memberikan contoh soal dan memberikan latihan soal. Pada proses pembelajaran, guru kurang memberikan kesempatan kepada siswa untuk terlibat dalam kegiatan memprediksi pola permasalahan apa yang dapat diamati, kegiatan pengamatan atau observasi, serta kegiatan yang dapat melatih retorika siswa yaitu mengkomunikasikan atau menjelaskan keterkaitan antara prediksi dan hasil observasi pada orang lain, sehingga kegiatan pembelajaran akan lebih bermakna bagi pemahaman siswa [4].

Faktor lain yang juga berpengaruh terhadap pemahaman konsep adalah proses pembelajaran yang dilakukan oleh guru yang belum mempertimbangkan gaya belajar siswa (Learning Style). Gaya belajar ini tidak mendapatkan perhatian lebih dari guru dalam memilih strategi atau model pembelajaran yang diterapkan. Gaya belajar seorang siswa menentukan bagaimana siswa dapat mengolah dan menyerap informasi, gaya belajar akan menjadikan seorang siswa mampu belajar dan berkomunikasi dengan lebih mudah.

Berdasarkan pemaparan di atas, pembelajaran yang efektif dapat membantu siswa dalam meningkatkan kemampuannya sesuai kompetensi dasar yang dicapainya. Meningkatkan cara belajar efektif dapat dilakukan dengan memperhatikan kondisi internal, eksternal, serta strategi, dan penggunaan model pembelajaran oleh guru dalam keefektifan proses pembelajaran memberi banyak kebebasan kepada peserta didik agar dapat melakukan pengamatan, belajar, dan mencari konsep masalah secara mandiri. Guru dituntut untuk mendesain suatu model pembelajaran efektif dan inovatif yang mengarah pada suatu peningkatan pemahaman konsep yang dimiliki oleh siswa.

Salah satu model pembelajaran yang dapat memfasilitasi siswa dalam mengembangkan kemampuan berfikir secara optimal, memperhatikan latar belakang kemampuan pemecahan masalah dengan strategi konflik kognitif dalam perubahan konseptual adalah model pembelajaran POE. Model pembelajaran yang dapat mengeksplorasi pengetahuan awal siswa, serta meningkatkan pemahaman konsep yang nantinya bermuara pada peningkatan hasil belajar siswa dengan model pembelajaran yang melibatkan peran aktif siswa untuk melakukan peningkatan proses kegiatan dalam pembelajar yang mendalam pada aktivitas strategi belajar dan desain belajar, di mana start belajar berasal dari segi pandang siswa bukan guru maupun ahli sains [3]. Pengetahuan dapat ditemukan, dibentuk, dan dikembangkan sesuai kemampuan yang dimiliki oleh siswa, tetapi guru hanya sebagai mediator atau fasilitator dalam membentuk maupun mengembangkan pengetahuan itu sendiri, bukan untuk memindahkan pengetahuan. Sehingga materi pelajaran yang diajarkan oleh guru tidak hnya menjadi 
bayangan bagi siswa, tetapi melihat dan melakukan praktik secara langsung selama proses pembelajaran, serta pemahaman siswa terhadap materi yang diajarkan akan menjadi lebih bermakna dan bermanfaat dalam penerapan kehidupan sehari-hari.

Beberapa penelitian mengenai strategi pembelajaran POE telah dilakukan di tingkat SMA. Salah satunya adalah penelitian yang dilakukan oleh [3] penelitian dengan judul "Penerapan Model Predict Observe Explain dengan Pendekatan Learning By Doing untuk meningkatkan hasil belajar siswa" menunjukkan bahwa model POE dengan pendekatan LBD dapat meningkatkan hasil belajar siswa. Selain penelitian yang telah dilakukan oleh [3] ada juga penelitian mengenai POE yaitu penelitian yang dilakukan oleh [2] yang berjudul "Penerapan Model Pembelajaran Predict Observe Explain (POE) Dilengkapi LKS Berbasis Drill And Practice untuk Meningkatkan Keaktifan Dan Prestasi Belajar Siswa Pada Materi Hidrolisis Garam Kelas XI IPA 3 Semester Genap SMA N 2 Karanganyar Tahun Pelajaran 2016/2017" menunjukkan bahwa dapat meningkatkan keaktifan dan prestasi belajar siswa yang terdiri dari aspek sikap, aspek pengetahuan, dan aspek keterampilan. Dengan kata lain model pembelajaran POE cocok diterapkan untuk meningkatkan ketertarikan siswa dalam mengikuti pembelajaran di dalam kelas.

Berdasarkan latar belakang tersebut maka peneliti berkeinginan untuk melakukan suatu penelitian yang bertujuan untuk mengetahui perbedaan kemampuan pemahaman konsep fisika siswa kelas $X$ anatara siswa yang mengikuti proses pembelajaran mengunakan model pembelajaran POE dengan pembelajaran yang menggunakan metoda konvensional.

\section{METODE}

Penelitian ini termasuk jenis penelitian eksperimen semu (Quasi Exsperiment) dengan desain penelitian the post-test only control group design. Populasi dari penelitian ini yaitu siswa kelas $X$ semester II SMA Negeri 2 Tejakula sebanyak 180 orang. Pengambilan sampel dilakukan dengan menggunakan teknik simple random sampling. Berdasarkan hasil undian secara random diperoleh kelas X2 yang berjumlah 28 orang dan X3 yang berjumlah 29 orang sebagai kelompok eksperimen yang total jumlahnya 57 orang, sedangkan kelas $X 4$ yang jumlahnya 32 orang dan $X 5$ yang jumlahnya 31 orang sebagai kelompok kontrol yang total jumlahnya 63 orang. Pengelompokkan siswa menurut gaya belajar didasarkan pada skor yang diperoleh siswa setelah mengerjakan tes gaya belajar. Jumlah total jawaban yang paling tinggi berdasarkan ketiga kategori gaya belajar menunjukkan siswa tersebut menonjol pada salah satu kategori dari gaya belajar tersebut. Dengan demikian, didapatkan hasil untuk masing-masing gaya belajar adalah sebagai berikut: untuk kelompok ekseprimen diperoleh jumlah siswa yang memiliki gaya belajar visual adalah 19, siswa yang memiliki gaya belajar auditori adalah 17 orang dan siswa yang memiliki gaya belajar kinestetika adalah 21 orang. Sedangkan untuk kelompok kontrol diperoleh jumlah siswa yang memiliki gaya belajar visual adalah 23 , siswa yang memiliki gaya belajar auditori adalah 18 orang dan siswa yang memiliki gaya belajar kinestetika adalah 22 orang.

Variabel terikat dalam penelitian ini adalah pemahaman konsep fisika. Variabel bebas terdiri dari model pembelajaran POE (MPPOE) pada kelompok eksperimen dan model pembelajaran konvensional (MPK) pada kelompok kontrol. Data yang dikumpulkan pada penelitian ini adalah pemahaman konsep fisika. Pemahaman konsep diukur dengan menggunakan tes pemahaman konsep fisika. Tes pemahaman konsep terdiri dari 25 butir soal pilihan ganda diperluas.

Aspek-aspek yang diukur dalam pemahaman konsep meliputi kemampuan menginterpretasi, memberikan contoh, mengklasifikasikan, merangkum, menduga, membandingkan, dan menjelaskan. Data dianalisis secara deskriptif dan ANOVA 2 jalur. Analisis deskriptif digunakan untuk mendeskripsikan skor rata-rata dan simpangan baku pemahaman konsep fisika. Sebelum pengujian hipotesis, terlebih dahulu dilakukan uji normalitas sebaran data dengan menggunakan statistik Kolmogorov-Smirnov dan Shapiro-Wilk, uji homogenitas varian antar kelompok menggunakan Levene's Test of Equality of Error Variance. Semua pengujian hipotesis dilakukan pada taraf signifikansi 0,05 . Adapun bentuk desain analisis ANOVA 2 jalur dengan rancangan treatment by level $2 \times 3$. Konstelasi variabel yang terlibat dalam penelitian ini disajikan pada Tabel 1 . 
Tabel 1 Konstelasi Variabel Penelitian

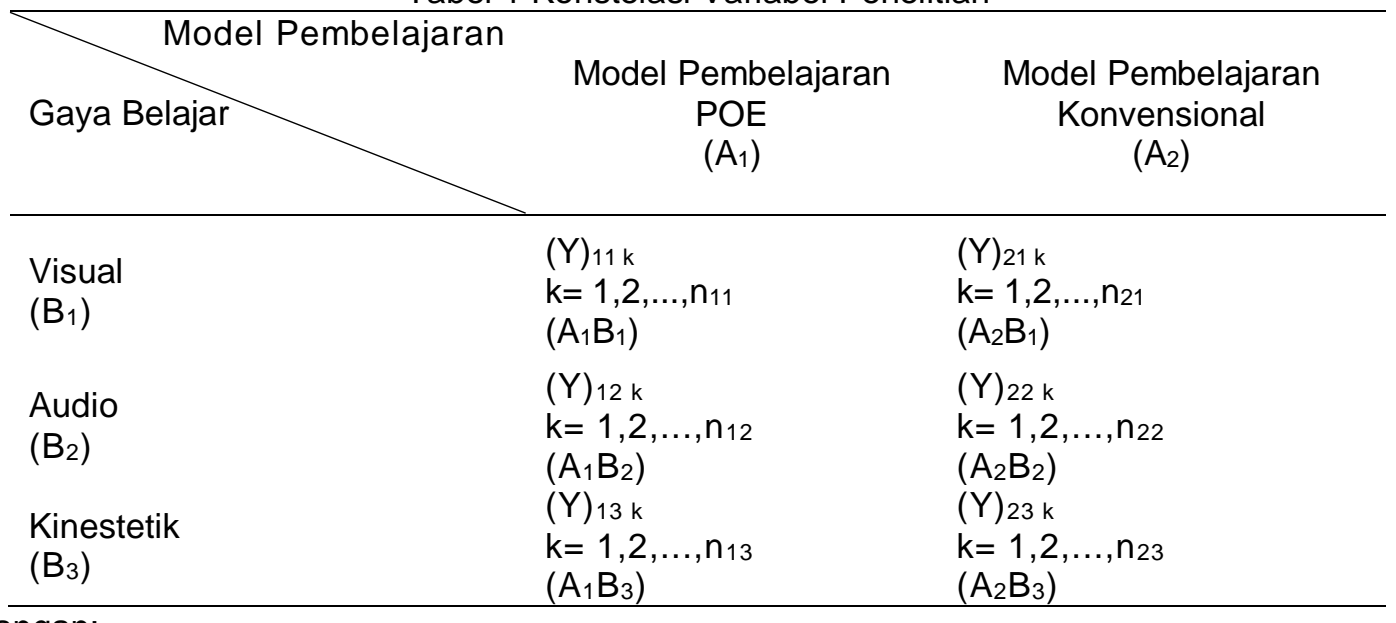

Keterangan:

$\mathrm{A}_{1} \quad=$ Kelompok siswa yang diberikan model pembelajaran $\mathrm{POE}$

$\mathrm{A}_{2}=$ Kelompok siswa yang diberikan model pembelajaran konvensional

$\mathrm{B}_{1} \quad=$ Kelompok siswa yang memiliki gaya belajar visual

$\mathrm{B}_{2}=$ Kelompok siswa yang memiliki gaya belajar audio

$\mathrm{B}_{3}=$ Kelompok siswa yang memiliki gaya belajar kinestetik

$\mathrm{A}_{1} \mathrm{~B}_{1}=$ Kelompok siswa yang diberikan model pembelajaran POE memiliki gaya belajar visual

$\mathrm{A}_{2} \mathrm{~B}_{1}=$ Kelompok siswa yang diberikan model pembelajaran konvensional memiliki gaya belajar visual

$\mathrm{A}_{1} \mathrm{~B}_{2}=$ Kelompok siswa yang diberikan model pembelajaran POE memiliki gaya belajar audio

$\mathrm{A}_{2} \mathrm{~B}_{2}=$ Kelompok siswa yang diberikan model pembelajaran konvensional memiliki gaya belajar audio

$\mathrm{A}_{1} \mathrm{~B}_{3}=$ Kelompok siswa yang diberikan model pembelajaran POE memiliki gaya belajar kinestetik

$\mathrm{A}_{2} \mathrm{~B}_{3}=$ Kelompok siswa yang diberikan model pembelajaran konvensional memiliki gaya belajar kinestetik

$\mathrm{Y} \quad=$ Pemahaman konsep

$\mathrm{k} \quad=$ Banyaknya sampel

Tahapan sederhana dari prosedur penelitian yang dilakukan dalam penelitian ini dapat ditampilkan dalam bentuk Gambar 1 sebagai berikut.

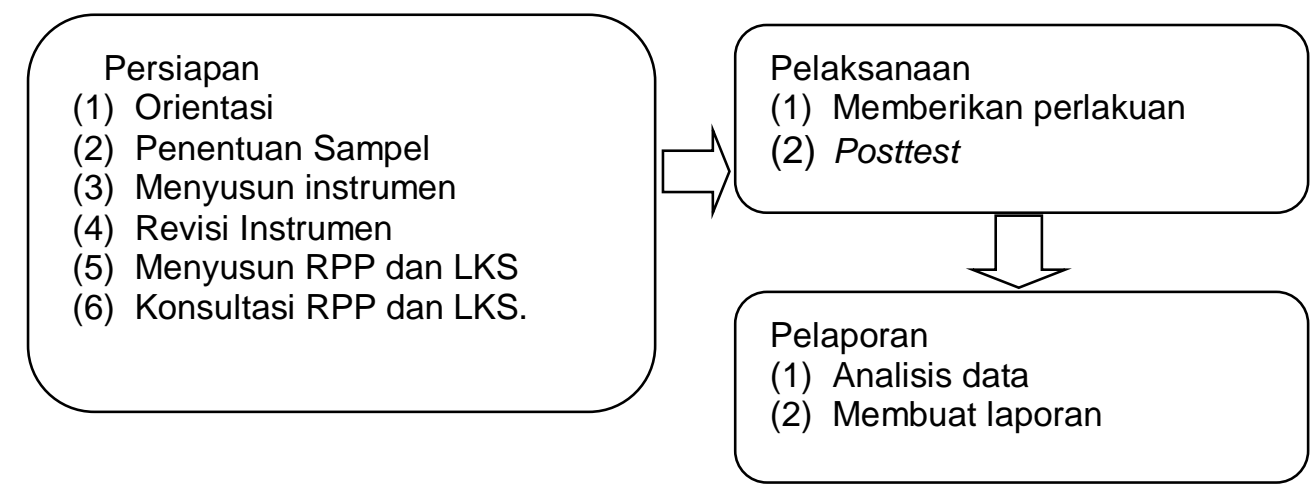

\section{Gambar 1. Prosedur Penelitian}

\section{HASIL DAN PEMBAHASAN}

Berdasarkan hasil penelitian berupa hasil posttest kemampuan pemahaman konsep, dapat dideskripsikan bahwa terdapat perbedaan kemampuan pemahaman konsep fisika siswa kelas $X$ antara kelas yang diberikan perlakuan menggunakan model pembelajaran POE dengan kelas yang menggunakan metoda pembelajaran konvensional. Hal ini terlihat dari hasil analisis data nilai posttest 
kemampuan pemahaman konsep siswa. Siswa kelas eksperimen lebih unggul diandingkan kelas kotrol. Berikut disajikan deskripsi data rerata nilai pemahaman konsep fisika yang mendapat pembelajaran model pembelajaran POE dan model pembelajaran konvensional, disajikan pada Tabel 2 .

Tabel 2. Deskripsi Nilai Pemahaman Konsep

\begin{tabular}{ccc}
\hline \multirow{2}{*}{ Statistik } & \multicolumn{2}{c}{ Pemahaman Konsep } \\
\cline { 2 - 3 } & MPPOE & MPK \\
\hline Jumlah data & 57 & 63 \\
Mean & 70,25 & 61,90 \\
SD & 9,01 & 5,12 \\
Maksimum & 88,00 & 76,00 \\
Minimum & 52,00 & 52,00 \\
\hline
\end{tabular}

Keterangan:

MPPOE $=$ model pembelajaran POE

MPK = model pembelajaran konvensional

Pada Tabel 2, dapat dilihat bahwa kelompok MPPOE menunjukkan pencapaian pemahaman konsep lebih baik dibandingkan dengan kelompok MPK.

\section{Pengujian Hipotesis}

Pada penelitian ini, Pengujian normalitas data menggunakan statistik Kolmogorov-Smirnov dan Shapiro-Wilk. Hasilnya menunjukkan bahwa nilai-nilai statistik yang diperoleh memiliki angka signifikansi lebih besar dari 0,05. Hal ini menyatakan bahwa sebaran data pemahaman konsep fisika berdistribusi normal. Berikut hasil pengujian normalitas disajikan pada Tabel 3.

Tabel 3 .

Uji Normalitas Berdasarkan Model Pembelajaran Dan Gaya Belajar

\begin{tabular}{rlrrrrrr}
\hline & & \multicolumn{3}{c}{ Tests of Normality } & \multicolumn{3}{c}{ Shapiro-Wilk } \\
\hline & & \multicolumn{2}{c}{ Kolmogorov-Smirnov } & Sig. \\
\cline { 3 - 9 } & MP_GB & Statistic & df & Sig. & Statistic & df & Sig. \\
\hline PK & MPPOE_GBV & .228 & 19 & .058 & .912 & 19 & .082 \\
& MPPOE_GBA & .203 & 17 & .060 & .939 & 17 & .310 \\
& MPPOE_GBK & .136 & 21 & $.200^{*}$ & .956 & 21 & .436 \\
& MPK_GBV & .231 & 23 & .062 & .901 & 23 & .063 \\
MPK_GBA & .178 & 18 & .135 & .952 & 18 & .453 \\
MPK_GBK & .188 & 22 & .118 & .889 & 22 & .180 \\
\hline
\end{tabular}

a. Lilliefors Significance Correction

*. This is a lower bound of the true significance.

Pengujian homogenitas varian mengunakan Levene's Test of Equality of Error Variances untuk pemahaman konsep fisika menunjukkan angka-angka signifikansi statistik Levene lebih besar dari 0,05 . Hal ini menunjukkan bahwa varian pemahaman konsep fisika adalah homogen. Berikut hasil pengujian normalitas disajikan pada Tabel 4.

Tabel 4 .

Uji Homogenitas Berdasarkan Model Pembelajaran Dan Gaya Belajar

\begin{tabular}{llrrrr}
\hline \multicolumn{5}{c}{ Test of Homogeneity of Variance } \\
\hline & $\begin{array}{c}\text { Levene } \\
\text { Statistic }\end{array}$ & df1 & \multicolumn{1}{c}{ df2 } & \multicolumn{1}{c}{ Sig. } \\
\hline PK & 3.746 & 5 & 114 & .135 \\
& Based on Mean & 2.845 & 5 & 114 & .185 \\
& Based on Median & 2.845 & 5 & 109.925 & .187 \\
Based on Median and & & & & \\
with adjusted df & 3.746 & 5 & 114 & .354 \\
\hline
\end{tabular}

Selanjutnya data dianalisis secara deksriptif dan dengan menggunakan ANOVA 2 jalur. Keseluruhan pengujian hipotesis dilakukan pada taraf signifikansi $5 \%$ menggunakan bantuan program SPSS 17.0 for Windows. Berdasarkan analisis, didapatkan hasil sebagai berikut. Pertama, terdapat 
perbedaan yang signifikan model pembelajaran terhadap pemahaman konsep fisika dengan $(F=28,177 ; p<0,05)$.

Kedua, terdapat perbedaan signifikan variabel pemahaman konsep fisika antara siswa yang memiliki gaya belajar visual, gaya belajar auditori dan gaya belajar kinestetika $(F=11,573 ; p<0,05)$. Ketiga, terdapat interaksi antara model pembelajaran dan gaya belajar terhadap pemahaman konsep fisika dengan $(F=11,000 ; p<0,05)$. Keempat, terdapat perbedaan signifikan variabel model pembelajaran terhadap pemhaman konsep fisika untuk siswa yang memiliki gaya belajar visual dengan $(F=23,912 ; p<0,05)$. Kelima, terdapat perbedaan signifikan variabel model pembelajaran terhadap pemahaman konsep fisika untuk siswa yang memiliki gaya belajar auditori dengan $(F=0,452 ; p<0,05)$. Keenam, terdapat perbedaan signifikan variabel model pembelajaran terhadap pemahaman konsep fisika untuk siswa yang memiliki gaya belajar kinestetika dengan ( $F=25,991$; $\mathrm{p}<0,05)$.

Profil interaksi variabel-variabel independen model pembelajaran (MPPOE dan MPK) dan gaya belajar (visual, auditori, dan kinestetika) terhadap variabel dependen pemahaman konsep fisika disajikan pada Gambar 2.

\section{Estimated Marginal Means of PK}

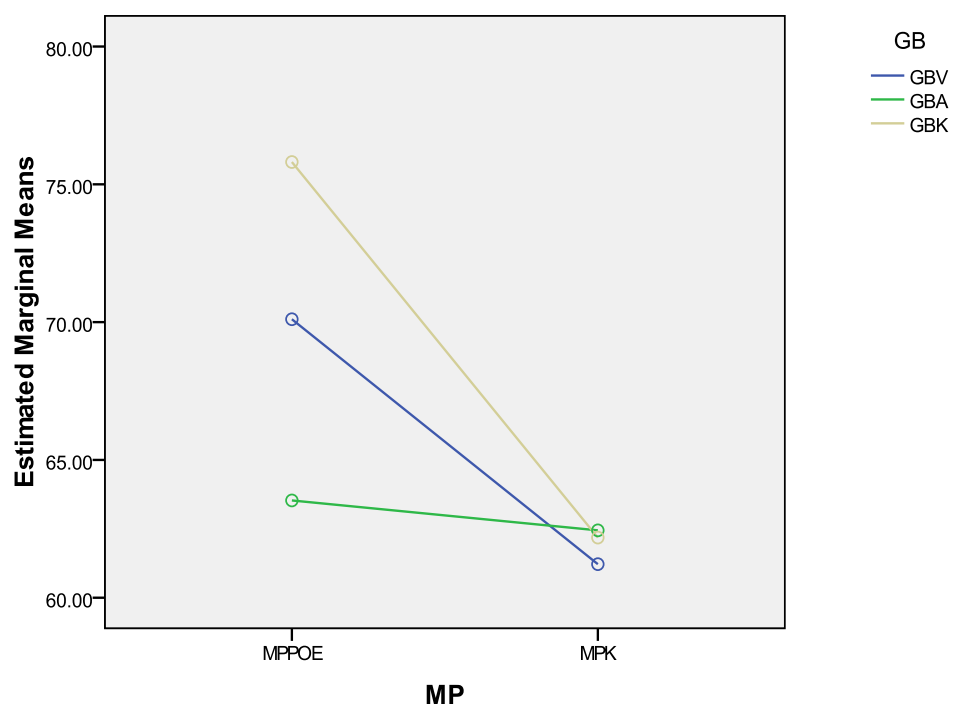

Gambar 2.

\section{Profil interaksi variabel MP vs GB dalam pencapaian Pemahaman Konsep}

Interaksi antara model pembelajaran dan gaya belajar terbukti berpengaruh terhadap pemahaman konsep fisika. Pengaruh paling baik terdapat pada interaksi model pembelajaran POE terhadap gaya belajar visual dan gaya belajar kinestetika. Keragaman karakteristik siswa merupakan hal unik yang harus dipahami guru. Melalui hasil penelitian yang telah dilakukan menunjukkan hasil secara kualitatif, dimana peserta didik yang memiliki kesulitan untuk memahami konsep materi yang diajarkan dapat terlihat dengan cepat menggunakan model POE. Kecepatan dalam mendiagnosis peserta didik yang memiliki kesulitan untuk memahami konsep materi dapat segera diatasi pada tahap observe dan explain. Penjelasan konsep pada peserta didik bagi yang memiliki kesulitan belajar pada tahap observe dan explain menjadi lebih mudah karena menggunakan konsep yang dekat dengan kehidupan peserta didik. Penggunaan model POE membuat siswa mempunyai banyak kesempatan untuk bertanya maupun mengungkapkan pendapatnya. Pembelajaran dengan menggunakan model POE dapat meningkatkan kesempatan siswa dalam mengkritik ide, menyampaikan pendapat dalam memperoleh pemahaman konsep yang benar.

Berdasarkan hasil penelitian di atas, penelitian ini bertujuan untuk melakukan pengujian terhadap pengaruh model pembelajaran MPPOE versus MPK untuk pencapaian pemahaman konsep fisika. Hasil penelitian dapat ditunjukkan bahwa terdapat perbedaan pemahaman konsep fisika yang signifikan antara kelompok siswa yang belajar dengan model POE dan kelompok siswa yang belajar dengan model pembelajaran konvensional dengan $F=28,177$ dengan angka signifikansi $0,00<0,05$. 
Berdasarkan hasil statistik deskriptif dapat dilihat bahwa nilai rata-rata Pemahanan konsep fisika MPPOE lebih baik jika dibandingkan dengan MPK. Hasil penelitian ini sesuai dengan teori yang sudah ada, dimana MPPOE memberikan nilai pemahaman konsep fisika yang lebih baik dibandingkan dengan MPK. Menurut [10] model pembelajaran POE adalah suatu model yang efektif untuk melakukan suatu diskusi bagi siswa terhadap konsep ilmu pengetahuan. Model pembelajaran POE dapat melibatkan siswa dalam memprediksi suatu fenomena, melakukan observasi melalui demonstrasi, dan menjelaskan hasil akhir dari demonstrasi dan ramalan siswa sebelumnya. Pembelajaran yang menggunakan model POE yang diguanakan oleh guru dapat memberikan pengertian yang mendalam pada aktivitas desain belajar dan strategi belajar yang menyatakan start belajar terbentuk dari sudut pandang siswa bukan guru maupun ahli sains.

Meningkatnya pemahaman konsep fisika dengan model POE, dapat dilihat dari langkahlangkah model pembelajarannya. Model pembelajaran POE memiliki 3 sintak dalam pembelajaran yaitu sebagai berikut [10], yaitu Predict, Observe, dan Explain. Prediksi (Prediction) adalah merupakan suatu proses membuat suatu taksiran terhadap suatu peristiwa/kejadian fisika. Dalam membuat sebuah taksiran siswa sudah memikirkan suatu alasan mengapa ia membuat taksiran seperti itu. Melalui proses tersebut siswa diberikan kebebasan seluas-luasanya untuk menyusun taksiran dengan alasan yang dimilikinya. Observasi (Observation) yaitu suatu kegiatan yang melakukan suatu penelitian, pengamatan tehadap kejadian yang telah terjadi. Dengan kata lain siswa diajak untuk melakukan eksperimen, untuk menguji suatu kebenaran dari hasil prediksi yang mereka sampaikan, hasil akhir dari tahap observasi selanjutnya dibahas secara bersama oleh siswa sehingga siswa memperoleh pengetahuan berdasarkan pengalaman mereka sendiri secara langsung. Melalui tahap ini siswa membuat eksperimen, untuk melakukan pengujian terhadap prediksi yang mereka ungkapkan atau sampaikan. Melalui tahap observasi siswa mendapatkan pengalaman dalam melakukan percobaan. Eksplanasi (Explanation) yaitu memberikan suatu penjelasan terhadap kesesuaian antara taksiran dengan hasil eksperimen dari tahap observasi. Peningkatan pemahaman siswa terjadi karena model pembelajaran POE dapat membantu siswa untuk membuktikan suatu konsep yang dimiliki siswa berdasarkan hasil penelusuran yang dilakukan oleh siswa sendiri. Di pihak lain, model pembelajaran konvensional lebih cenderung bersifat teacher centered. Model pembelajaran konvensional memiliki tahapan-tahapan pembelajaran yaitu apersepsi oleh guru, penyajian informasi, ilustrasi dan contoh soal, latihan soal, dan umpan balik. Tampak bahwa tahapantahapan pembelajaran tersebut bersifat kurang dinamis dan fleksibel. Siswa hanya menerima apa yang telah diajarkan oleh guru.

Hasil penelitian ini sangat mudah dipahami karena sintaks model pembelajaran POE yang terdiri dari tahap prediction, observation and explanation dan prosedur metode eksperimen yang dilakukan selama proses pembelajaran berlangsung mampu mengakomodasi siswa untuk memperoleh pemahaman konsep yang benar melalui aspek kognitif, afektif maupun psikomotor. Jenis pemahaman konsep fisika baik dasar maupun terintegrasi akan terlatih dengan baik melalui penerapan strategi pembelajaran tersebut. Sebagai contoh sebelum siswa melakukan percobaan maka pada tahap prediction siswa berlatih memprediksi/meramalkan hasil percobaan, sehingga hal ini akan menunjang sikap siswa mengenai predicting yang merupakan sikap ilmiah dasar siswa. Selama tahap observation siswa melaksanakan eksperimen sesuai prosedur metode ilmiah, dimulai dari perumusan masalah yang menunjang aspek sikap siswa. Selanjutnya siswa berlatih mengkomunikasikan hasil percobaan yang telah dilakukan secara tertulis maupun lisan yang merupakan aspek dari pemahaman konsep fisika dan sikap siswa komunikasi (communicating). Komunikasi merupakan salah satu perwujudan dari tahap explanation dari model pembelajaran POE[5].

Beberapa penelitian yang dilakukan oleh para ahli mengenai strategi pembelajaran POE diberbagai tingkat pendidikan. Salah satunya adalah penelitian yang dilakukan oleh [6] yang berjudull Implementasi Model Pembelajaran POE (Predict Observe Explain) Untuk Meningkatkan Pemahaman Konsep Siswa Pada Materi Hukum Newton. Penelitian yang dilakukan oleh Rosdianto. H menunjukkan bahwa Peningkatan pemahaman konsep siswa diketahui dari rata-rata hasil posttest yang lebih tinggi dari rata-rata hasil pretest. Diperolehnya hasil pemahaman kosep dengan menggunakan persamaan $\mathrm{N}$-gain yaitu sebesar 0,64 dengan kategori sedang. Hal ini membuktikan bahwa model pembelajaran POE dapat meningkatkan pemahaman konsep siswa kelas VIII pada materi hukum Newton, sedangkan penguasaan konsep siswa di kelas control berada pada kategori rendah.

Selain itu, gaya belajar merupakan salah satu faktor internal yang dimungkinkan dapat mempengaruhi hasil belajar siswa. Gaya belajar merupakan kombinasi dari bagaimana seseorang menyerap, kemudian mengolah dan mengatur informasi. Seseorang yang memahami gaya belajarnya 
sendiri, akan mampu memanfaatkan langkah-langkah penting untuk membantu kecepatan dirinya untuk belajar lebih mudah. Demikian pula dalam mencapai tujuan pembelajaran di sekolah, diharapkan guru maupun siswa mampu memahami kecenderungan gaya belajar yang dimiliki. Faktor internal gaya belajar siswa tidak terakomodasi dengan baik sangat mungkin menyebabkan tidak tercapainya tujuan pembelajaran. Diperlukan dukungan strategi dalam penyesuaian proses pembelajaran dan mampu mengakomodasi keragaman yang unik dari masing-masing siswa. Dalam penelitian ini siswa dikatagorikan memiliki kecenderungan gaya belajar visual dan kinestetik. Walaupun masing-masing siswa belajar dengan menggunakan dua modalitas kemampuan pada tahapan tertentu, tetapi kebanyakan siswa lebih cenderung menggunakan kemampuannya pada salah satu di antara keduanya.

Gaya belajar memiliki ciri khas tersendiri. Untuk gaya belajar visual, yang memegang peranan penting adalah indera penglihatan (mata). Siswa yang dominan memiliki gaya belajar visual lebih nyaman belajar, apabila gurunya membawakan alat peraga/media dalam pembelajaran atau dengan langsung mengajak ke objek-objek yang saling keterkaitan dengan konsep yang dikaji. Siswa dyang memiliki gaya belajar visual, sangat memperhatikan ekspresi wajah dan bahasa tubuh yang dimiliki gurunya. Gaya belajar auditori, mengandalkan kesuksesan belajar melalui indera pendengaran (telinga). Siswa yang dominan memiliki gaya belajar auditori merasa nyaman belajar, apabila belajar dengan berdiskusi secara lisan dan mendengarkan apa yang dikatakan guru. Siswa yang memiliki gaya belajar auditori, perolehan belajarnya sangat dipengaruhi oleh tone suara, pitch (tinggi rendahnya), kejelasan berbicara. Gaya belajar kinestetika, mengandalkan keberhasilan dirinya dalam belajar melalui gerakan dan emosi. Siswa yang dominan memiliki gaya belajar kinestetika, lebih nyaman belajar, apabila belajar dengan mengasosiasikan gerakan pada setiap fakta.

Gaya belajar dalam kegiatan pembelajaran memegang peranan penting dalam proses pembelajaran. Penggunaan gaya belajar yang sesuai dengan yang dimiliki siswa dalam proses pembelajaran dapat memudahkan siswa dalam menyerap dan memahami suatu informasi yang didapat dari proses pembelajaran[8]. Pencapaian hasil belajar antara siswa yang satu dengan yang lainnya tidak serta-merta sama karena dipengaruhi oleh beberapa faktor baik yang ada di dalam diri siswa maupun di luar diri siswa, namun dalam proses pembelajaran faktor yang ada dalam diri siswa menjadi faktor terpenting yang erat hubungannya dengan diri siswa dalam kegiatan pembelajaran yang berlangsung. Siswa yang memahami gaya belajarnya sendiri mampu melakukan langkahlangkah penting dalam membantu dirinya untuk belajar lebih cepat dan mendapat hasil belajar yang maksimal. Oleh karena itu gaya belajar siswa sangat berperan penting dalam pencapaian hasil belajar siswa tersebut.

Dalam pencapaian pemahaman konsep, secara konsisten model pembelajaran POE lebih dapat memfasilitasi gaya belajar dibandingkan dengan model pembelajaran konvensional. Sedangkan antar gaya belajar visual, gaya belajar auditori, dan gaya belajar kinestetika, gaya belajar visual yang paling cocok difasilitasi dengan model pembelajaran POE, kemudian disusul dengan gaya belajar kinestetika, dan gaya belajar auditori, dan gaya belajar auditori paling cocok dibelajarkan dengan model pembelajaran konvensional. Kecenderungan gaya belajar visual yang lebih berperan dalam memperkuat interaksi ini dimungkinkan karena sebagian besar pelaksanaan strategi pembelajaran yang dilaksanakan dalam penelitian ini banyak melibatkan indera penglihatan. Keadaan ini dapat dipahami karena jenis hasil belajar yang diukur dalam penelitian ini pemahaman konsep dan sikap ilmiah siswa yang banyak melibatkan indera penglihatan.

Penerapan model pembelajaran POE sebenarnya telah memberdayakan siswa secara fisik yang melibatkan seluruh indera siswa. Untuk gaya belajar visual, kekuatan belajarnya ditentukan oleh penglihatan. Siswa yang memiliki gaya belajar visual, lebih dapat menangkap makna apabila materi pembelajaran disertai dengan alat peraga/media visual. Sedangkan, bagi siswa yang memiliki gaya belajar auditori, keberhasian belajarnya ditentukan oleh pendengarannya. Siswa ini lebih optimal belajar apabila memperhatikan ekspresi wajah gurunya. Penekanan terhadap irama dan intonasi suara dapat membantu siswa yang memiliki gaya belajar auditori dalam menangkap makna dari apa yang dikaji. Untuk siswa yang memiliki gaya belajar kinestetika, keberhasilan belajarnya bertumpu pada gerakan. Untuk mencapai perolehan belajar yang baik, siswa jenis ini penting diberikan kesempatan menyentuh langsung benda/objek nyata yang dikaji. Peberian kesempatan untuk berjalan-jalan dikelas atau menggerak-gerakkan kakinya, dapat menciptakan kenyamanan belajar bagi siswa yang memiliki gaya belajar kinestetika[7].

Dengan model POE, dalam proses pembelajaran siswa lebih aktif dalam membuktikan suatu konsep berdasarkan hasil pengamatan dan analisis data yang mereka lakukan sendiri. Hasil pengamatan data dan analisis data dilakukan baik dengan cara praktikum dan maupun melalui studii literatur yang dilakukan oleh mereka sendiri. Keaktifan peserta didik dalam membuktikan suatu 
konsep, menjadikan pengetahuan yang mereka dapat menjadi jauh lebih bermakna. Jadi, secara keseluruhan model pembelajaran predict Observe Explain (POE) ini dapat meningkatkan pemahaman konsep siswa pada mata pelajaran fisika, karena dengan menggunakan model ini siswa dapat lebih aktif, interaksi antara siswa dan guru menjadi lebih baik dan dapat belajar secara bermakna sehingga materi yang diajarkan tetap diingat dan tidak mudah untuk dilupakan.

\section{SIMPULAN DAN SARAN}

Berdasarkan hasil penelitian dan pembahasan diuraikan simpulan sebagai berikut. Terdapat perbedaan pemahaman konsep fisika antara kelompok siswa yang belajar dengan model POE dan model pembelajaran konvensional $(F=28,177 ; p<0,05)$. Terdapat perbedaan pemahaman konsep fisika antara siswa yang memiliki gaya belajar visual, gaya belajar auditori dan gaya belajar kinestetika $(F=11,573 ; p<0,05)$. Terdapat pengaruh interaksi antara model pembelajaran dan gaya belajar terhadap pemahaman konsep fisika dan sikap ilmiah siswa $(F=11,000 ; p<0,05)$. Terdapat perbedaan pemahaman konsep fisika antara kelompok siswa yang belajar dengan model POE dan model pembelajaran konvensional untuk siswa yang memiliki gaya belajar visual $(F=23,912 ; p<0,05)$. Terdapat perbedaan pemahaman konsep fisika antara kelompok siswa yang belajar dengan model POE dan model pembelajaran konvensional untuk siswa yang memiliki gaya belajar auditori $(F=0,452$; $\mathrm{p}<0,05)$. Terdapat perbedaan pemahaman konsep fisika antara kelompok siswa yang belajar dengan model POE dan model pembelajaran konvensional untuk siswa yang memiliki gaya belajar kinestetika $(F=25,991 ; p<0,05)$. Hal ini menyatakan bahwa model pembelajaran POE dapat meningkatkan pemahaman konsep fisika pada siswa.

Saran yang dapat diberikan: 1) Sistem pembelajaran menggunakan model pembelajaran POE dapat diterapkan secara maksimal, sehingga dapat meningkatkan pemahaman konsep fisika pada siswa. 2) Guru dalam menggunakan model POE dapat memperhatikan sintak atau kegiatan pembelajaran sertaaspek-aspek yang mempengaruhi kualitas pembelajaran sehingga memudahkan bagi peserta didik dalam proses pembelajaran berpusat pada siswa sebagai salah satu alternative untuk menggunakan model pembelajaran inovatif yang sesuai dengan dengan karakteristik pembelajara fisika dalam upaya meningkatkan pemahaman konsep, aktivitas belajar, hasil belajar siswa dan mengurangi proses pembelajaran yang terpusat pada guru. 3) Perlu dilakukan penelitian lebih lanjut tentang penggunaan model pembelajaran POE dengan menggunakan metoda lain pada pokok bahasan yang lain, mata pelajaran, kelas, dan tempat penelitian yang berbeda untuk mendapatkan gambaran yang lebih meyakinkan mengenai penerapan model pembelajaran POE untuk meningkatkan pemahaman konsep siswa.

\section{DAFTAR PUSTAKA}

[1] Anderson, Lorin W, dan David R. Krathwohl. Pembelajaran, Pengajaran, dan Asesmen. Yogyakarta: Pustaka Pelajar. 2010.

[2] Ariyanti. L., Utami. B., dan Susanti. E. 2018. Penerapan Model Pembelajaran Predict Observe Explain (POE) Dilengkapi Lks Berbasis Drill And Practice Untuk Meningkatkan Keaktifan Dan Prestasi Belajar Siswa Pada Materi Hidrolisis Garam Kelas XI IPA 3 Semester Genap SMA N 2 Karanganyar Tahun Pelajaran 2016/2017. Jurnal Pendidikan Kimia., Vol. 7, No. 1.

[3] Herniati. R., Sulistri. E., dan Rosdianto. H. 2017. Penerapan Model Predict Observe Explain dengan Pendekatan Learning By Doing untuk Meningkatkan Hasil Belajar Siswa. Jurnal Fisika Flux., Vol. 14, No. 2.

[4] Kurniasih, Imas \& Berlin Sani. 2015. Ragam Pengembangan Model Pembelajaran: Untuk Peningkatan Profesionalitas Guru. Jakarta: Kata Pena.

[5] Rohmani, S., Sunarno, W., dan Aminah, N. S. 2015. Pembelajaran Fisika Menggunakan Model POE (Prediction, Observation, and Explanation) Melalu Metode Eksperimen dan Proyek Ditinjau Dari Kreativitas dan Sikap IImiah Siswa. Jurnal Inkuiri. Vol. 4, No. 4.

[6] Rosdianto. H., Murdani. E., dan Hendra. 2017. Implementasi Model Pembelajaran POE (Predict Observe Explain) untuk Meningkatkan Pemahaman Konsep Siswa pada Materi Hukum Newton. Jurnal Pendidikan Fisika. Vol. 6, No. 1.

[7] Surjono, H. D., \& Nurkhamid. 2014. Pengembangan Model E-Learning Adaptif terhadap Keragaman Gaya Belajar Mahasiswa untuk Meningkatkan Efektivitas Pembelajaran. Laporan Penelitian. (tidak diterbitkan). Universitas Negeri Yogyakarta. 
[8] Sugiyono. Gaya belajar pada peserta didik. Kencana. Jakarta. 2016.

[9] Warsono dan Hariyanto. 2014. Pembelajaran Aktif. Bandung: PT Remaja Rosdakarya Offset.

[10] Yupani, Garminah, dan Mahadewi. 2014. Pengaruh Model Pembelajaran Predict-Observe-Explain (POE) Berbantuan Materi Bermuatan Kearifan Lokal terhadap Hasil Belajar IPA Siswa Kelas IV. Laporan Penelitian Universitas Pendidikan Ganesha. 